UDK $627.51: 001.8$

Oleksiy V. Petrochenko, $\mathrm{PhD}$, Assistant_Rector

https://orcid.org/0000-0002-0551-935X e-mail: a_petr89@i.ua

Kyiv National University of Construction and Architecture, Kyiv, Ukraine

\title{
ASSESSMENT AND PREDICTION OF FLOOD RISKS IN RIVER BASINS
}

Abstract. The problem of floods is considered as an essential component of the modern global problem of water on the planet. Given the structural complexity of the flood problem and the urgent need to address it in Ukraine, the need and feasibility of creating a perfect methodology for integrated flood risk management in river basins has been stated. It is noted that an important component of the methodology of integrated flood risk management in river basins is flood assessment and forecasting. The article is devoted to the development of scientific and methodological foundations for assessing and forecasting flood risks in river basins. Floods are classified according to their intensity. Two main types of flood protection in river basins are distinguished - situational and preventive. A criterion is given by which it is advisable to choose the type of flood protection in river basins. Depending on the type of flood protection chosen, flood protection measures are divided into situational and preventive. A fundamental approach to the management of flood protection of a situational type is provided, according to which short-term forecasting of the flood and the subsequent implementation of response measures during the approach, passage and completion of the flood are provided. The basic principles of flood control of a preventive type are described, according to which long-term forecasting of floods and the implementation of response measures through the construction and operation of flood control structures is provided. It was noted that there were no perfect methods for longterm flood forecasting, in connection with which an attempt was made to develop a fundamentally new flood forecasting methodology, which is based on the use of statistical data on past flood situations. It is proposed to perform long-term flood forecasting according to hydrological indicators of floods and indicators of their consequences. The long-term flood forecasting technique is based on the approximation of the flow rate of the water flow and the total flood losses in the form of descending hyperbolic functions depending on the flood intensity. The main result of long-term flood forecasting is the amount of total flood damage projected for the next 99 years that is found by integrating the flood loss function. Predicted flood losses form the basis of the dependencies for determining the main indicators of the effectiveness of preventive flood control measures - the average annual prevented damage and damage prevented during the estimated life of protective structures.

Keywords: system analysis; flood; flood classification; flood zone; flood consequences; flood protection; projected losses; prevented losses

(C) O. V. Petrochenko, 2020 


\title{
О.В. Петроченко
}

Київський національний університет будівництва і архітектури, м. Київ, Україна

\section{ОЦІНКА І ПРОГНОЗУВАННЯ ПАВОДКОВИХ РИЗИКІВ В РІЧКОВИХ БАСЕЙНАХ}

\begin{abstract}
Анотація. Розглянуто проблему паводків як суттєву складову сучасної глобальної проблеми води на планеті. 3 огляду на структурну складність проблеми паводків та актуальну потребу ї̈ рімення в Україні зазначена необхідність і доцільність створення досконалої методологї інтегрованого управління паводковими ризиками в річкових басейнах. Зазначається, щзо важливою складовою методології інтегрованого управління паводковими ризиками в річкових басейнах є оцінка паводків та їх прогнозування. Стаття присвячена розробці науково-методичних основ очінки $i$ прогнозування паводкових ризиків в річкових басейнах. Виконано класифікацію паводків за показником їх забезпеченості. Виділено два основних типи протипаводкового захисту в річкових басейнах - ситуачійний $i$ превентивний. Наведено критерій, за яким дочільно обирати тип протипаводкового захисту в річкових басейнах. Залежно від обраного типу протипаводкового захисту заходи захисту від паводків поділено на ситуаційні і превентивні. Наведено принциповий підхід до управління протипаводковим захистом ситуачійного типу, за яким передбачено короткострокове прогнозування паводку та наступне здійснення заходів реагування в період його наближення, проходження та завершення. Викладено принципові основи управління протипаводковим захистом превентивного типу, за яким передбачено довгострокове прогнозування паводків та здійснення заходів реагування иляхом будівництва та експлуатації протипаводкових споруд. Наголошено про відсутність досконалих методів довгострокового прогнозування паводків, в зв'язку з чим зроблено спробу розробити принщипово нову методику прогнозування паводків, яка трунтується на використанні статистичних даних паводкових ситуащій минулих років. Довгострокове прогнозування паводків запропоновано здійснювати за гідрологічними показниками паводків $i$ показниками наслідків їх проходження. Основу методики довгострокового прогнозування паводків становить апроксимація спадними гіперболічними функиіями витрати паводкового потоку $і$ загальних збитків залежно від забезпеченості паводків. Основним результатом довгострокового прогнозування паводків є прогнозована на майбутні 99 років сума загальних збитків від паводків, яку знаходять шляхом інтегрування гіперболічної функиії збитків від паводків. Прогнозовані збитки від паводків покладено в основу розрахункових залежностей визначення основних показників ефективності превентивних протипаводкових заходів середньорічних відвернених збитків $i$ збитків, відвернених протягом розрахункового строку експлуатації захисних протипаводкових споруд.
\end{abstract}

Ключові слова: системний аналіз; паводок; класифікаџія паводків; зона затоплення; наслідки паводків; захист від паводків; прогнозовані збитки; відвернені збитки

\section{Вступ}

На сучасному етапі розвитку земної цивілізації проблема води визначилась як одна з глобальних проблем людства. Проблема води - це не одна, а дві протилежні за характером впливу на життєдіяльність людини проблеми: 
проблема дефіциту води необхідної якості у посушливих регіонах планети і проблема надлишку води у вигляді весняних повеней та дощових паводків.

Проблема дефіциту води має місце в країнах і регіонах недостатньо забезпечених власними водними ресурсами. Недостатня забезпеченість водою ускладнює, а в деяких країнах унеможливлює рішення національних продовольчих задач. Забезпеченість країн власними водними ресурсами визначають показником $w$ обсягу місцевого річкового стоку в тис. ${ }^{3}$, що припадає в один рік на одну людину. За визначенням Європейської економічної комісії ООН, країна, в якій місцевий річковий стік становить менше 1,7 тис. м³/рік на 1 людину, вважається водонезабезпеченою. Згідно 3 базою даних міжнародної економічної статистики StatInfo.biz Україна має показник $w=1,1$ тис. $\mathrm{m}^{3} /$ рік на одну людину. За показником забезпеченості власними водними ресурсами Україна займає 54-те місце серед 68 найбільших країн світу і 25-те місце серед 30 європейських країн [1].

Незважаючи на загальний дефіцит води в Україні, в пї північно-західних областях існує проблема надлишку води або проблема повеней і паводків. Повінь - це фаза водного режиму річки, яка спостерігається щорічно, настає в один і той же сезон і характеризується значним підвищенням рівня води в річці внаслідок весняного танення снігу. Паводок - фаза водного режиму річки, яка характеризується відносно короткочасним підняттям рівня води в річці під час зливових дощів, аварій на гідротехнічних спорудах, інтенсивного танення снігів при відлизі. Паводок, на відміну від повені, має більш універсальне визначення, оскільки він може мати місце в різні періоди року, а повінь можна вважати паводком, який проходить щовесни. Тому в подальшому для зручності викладення результатів досліджень проблема повеней і паводків розглядається як проблема паводків.

Існування проблеми паводків в Україні, в умовах недостатньої забезпеченості власними водними ресурсами, пояснюється тим, що 70\% річкового стоку країни припадає на їі північно-західні області, де проживає 40\% населення, а 30\% річкового стоку припадає на південно-східні області, де проживає 60\% населення і знаходиться 70\% агропромислового комплексу [2]. У зв'язку з цим розподіл забезпеченості регіонів України власними водними ресурсами має яскраво виражений контрастний характер. В південно-східних областях (Херсонська, Миколаївська, Запорізька, Донецька) показник забезпеченості власними водними ресурсами становить $w=0,3 \ldots 0,45$ тис. $\mathrm{m}^{3} /$ piк на 1 людину, що створює гострий дефіцит води в цих областях. Проте в західних областях (Івано-Франківська і Закарпатська) цей показник досягає найбільших в Україні значень: $w=3,0 \ldots 7,0$ тис. м³/рік на 1 людину. Достатньо великий річковий стік гірських річок Українських Карпат та край нерівномірний розподіл річкового стоку протягом року створюють проблему надлишку води або проблему паводків в Карпатському регіоні, де паводки мають найбільш руйнівний характер і можуть повторюватись 3-8 разів на рік [3].

Проблема паводків ускладнює умови проживання населення в заплавах $\mathrm{i}$ долинах річок. Рішення цієї проблеми $є$ надзвичайно актуальним, оскільки прирічкові угіддя на усіх етапах розвитку цивілізації завжди приваблювали людей. Заплави і луки використовувались для тваринництва. Річкові долини використовувались для рільництва та городництва. Долинні тераси використовувались для розміщення поселень, доріг та комунікацій. Річкові 
водні ресурси використовувались для судноплавства, питного, господарського та промислового водопостачання.

Проблемі паводків присвячено багато наукових праць, в яких основним напрямом досліджень було вивчення гідрологічних характеристик паводків за минулі роки, а також наслідків їх проходження в руслах, заплавах та долинах річок. За результатами попередніх досліджень створено широку базу статистичних даних проходження паводків різної інтенсивності в річкових басейнах країн світу і в Україні [4-7]. Проте для ефективного рішення проблеми паводків виникає потреба систематизації результатів попередніх досліджень небезпечних явищ, викликаних паводками, та створення досконалої методології інтегрованого управління паводковими ризиками в річкових басейнах. Однією 3 найбільш важливих складових методології інтегрованого управління паводковими ризиками в річкових басейнах є оцінка інтенсивності паводків та їх прогнозування.

Мета дослідження - виконати аналіз паводкових ситуацій в Україні за попередні роки та розробити науково-методичні засади оцінки та прогнозування паводків за гідрологічними показниками i наслідками їх проходження в річкових басейнах.

В основу досліджень покладено методологію системного аналізу.

\section{Результати дослідження}

\section{1 Аналіз паводкових ситуацій в Україні за попередні роки}

Майже на 27\% території країни, а це 165 тис. км², де проживає майже третина населення, є прояви шкідливої дії паводків. Практично не існує жодної території України, де періодично не підвищувалась водність річки під час дощів та танення снігу та не відчувалася шкідлива дія паводків [8, 9]. Найбільше від паводків потерпає населення гірських та передгірських районів Карпат. Крім того, більше половини освоєних площ гірських схилів у Закарпатській, Івано-Франківській, Львівській та Чернівецькій областях піддаються впливу зсувних процесів і селів, які формуються вже як наслідок літніх паводків. У підсумку населення й економіка країни зазнають значних збитків. Паводки руйнують водозахисні споруди, житлові будинки, мости, дороги, промислові об'єкти, завдають збитки сільському та водному господарству, лісовому фонду. Паводки замулюють низинні заплавні землі, ініціюють ерозійні процеси. Після проходження паводків різко зростає градієнт підземного потоку, що призводить до суфозії грунту, зсувів та утворення селевих потоків. Шкідлива дія паводків створює серйозну соціально-економічну загрозу в Україні і перш за все в Карпатському регіоні. Це підтверджується статистикою паводків, починаючи 3 кінця ХІХ століття [5-7, 9-17]:

- 2-3 квітня 1897 р. пройшов катастрофічний паводок на р. Прут [12];

- 8-9 липня 1911 р. внаслідок сильних злив рівень води на річці Прут нижче впадання в річку Черемош сягав найвищих позначок, які не були перевершені до цього часу, а рівні води в передгірній частині р. Серет були перевищені лише в період паводку 23-30 липня 2008 р. Максимальна витрата паводкового потоку біля м. Чернівці становила $5250 \mathrm{~m}^{3} / \mathrm{c}$, а швидкість течії становила 5-6 м/с. Орієнтовна витрата води р. Серет тоді сягала близько 1000 м³/с, що приблизно в 100 разів перевищує меженний стік [9-11]; 
- 30-31 серпня 1927 р. у басейні річок Дністра і Прута за два дні випали опади кількістю понад 300 мм. В низинах паводком було затоплено понад 10 міст та багато сіл $[6,9]$;

- 12 липня 1929 р. спостерігався паводок на р. Серет, який відноситься до великих. На гідрологічному посту у м. Сторожинець максимальна витрата води становила $796 \mathrm{~m}^{3} / \mathrm{c}$ при середньорічній близько $6 \mathrm{~m}^{3} / \mathrm{c}$, ширина зони затоплення берегів сягала 236 м [12];

- 1-2 вересня 1941 р. в басейні річок Дністра, Пруту і Серету пройшов надзвичайно великий паводок з ймовірністю 1 раз на 250-300 років. Рівні води в Дністрі на 1-3 м перевищили максимальні рівні води попередніх років $[6,9,12]$;

- 7-15 червня 1969 р. випали тривалі й інтенсивні опади, які викликали катастрофічний паводок в р. Серет та сформували найвищі за останні 100 років рівні води в руслі річки $[6,13]$;.

- 8 липня 1999 р. трапився паводок в гірській частині річки Серет на ділянці між населеними пунктами Долішній Шепіт і Берегомет Вижницького району. Внаслідок раптової зливи в горах рівні води в річці піднялись на 3-4 м. Прорвало греблю, утворився вал води. Зруйновано 8 мостів, 10 км доріг, пошкоджено 15 садиб, затоплено 70 га городів. У низині виникла штучна водойма. Загинуло 2 особи. Збитки становили близько 1,3 млн грн [16];

- 3-5 березня 2001 р. на території Закарпатської області випало дві норми місячних опадів. Рівні води в деяких річках на 1,5-2 м перевищили рівні води паводку 1998 р. Об'єм опадів, які сформували цей паводок, становив 2 млрд м ${ }^{3}$ води. Паводок спричинив величезні руйнування та призвів до загибелі 9 чоловік [9];

- 23-30 липня 2008 р. відбувся паводок, який за територією охоплення був регіональним, а за наслідками - катастрофічний. 28 липня на території Львівської, Закарпатської, Тернопільської, Чернівецької та Івано-Франківської областей було підтоплено $40 \quad 601$ житловий будинок i $33 \quad 882$ га сільськогосподарських угідь, пошкоджено 360 автотранспортних мостів і 561 пішохідний міст, розмито 681 км автомобільних доріг, постраждало 150 тис. осіб, загинуло 38 осіб $[9,17]$.
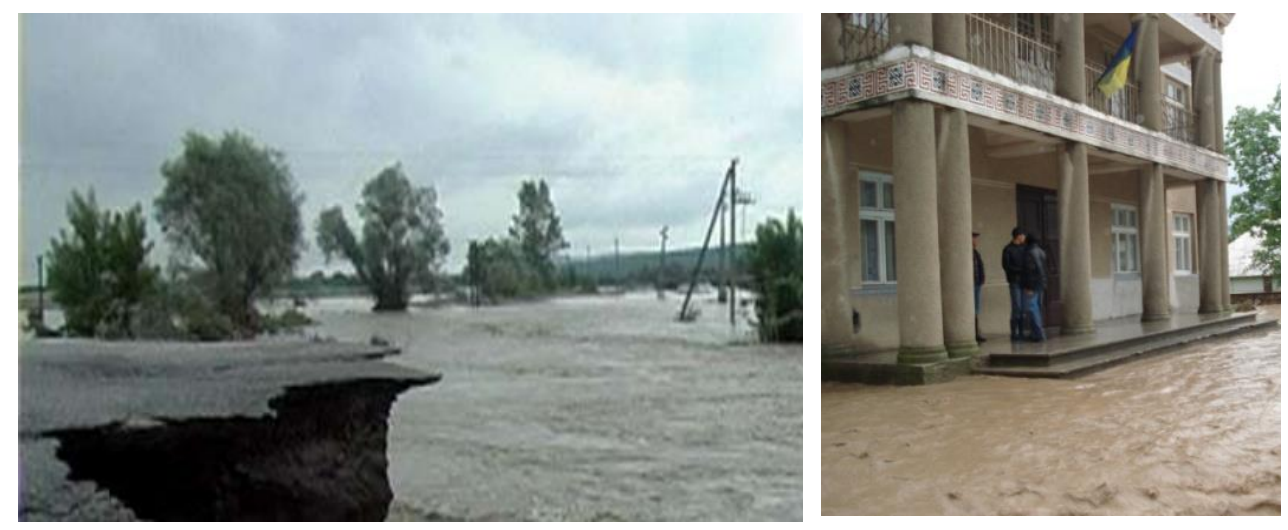

Рис. 1 - Паводок в басейні Дністра на Прикарпатті у липні 2008 р. 
Середньорічні збитки від паводків у 1995-1998 рр. склали 899,3 млн грн, у 1999-2007 pp. - понад 1,5 млрд грн [26], а у 2008 р. - близько 6 млрд грн [9].

Причини виникнення паводків можна поділити на дві групи: природні та антропогенні $[9,14,15,17]$. Природними чинниками виникнення паводків $\epsilon$ атмосферні опади, танення снігів. До антропогенних чинників слід віднести: руйнування природних стоків та порушення природного стану гірських схилів внаслідок будівництва лінійно-протяжних інженерних комунікацій, що перетинають водні джерела, незаконного видобутку піску і гравію в руслах річок тощо. Порушення природного стану гірських схилів відбувається внаслідок вирубки лісів на схилах, розорювання схилів.

Проблема захисту від паводків набуває особливого значення. Території, що знаходяться в зонах періодичного затоплення паводками i повенями, потребують надійного захисту [4-8]. Проблема протипаводкового захисту невіддільна від загальних задач збереження та відтворення водних ресурсів, покращення якості вод та забезпечення їх екологічної безпеки при користуванні. Шляхи та способи вирішення цієї проблеми відображено у Водному кодексі України, у Директиві 2007/60/СР Європейського Парламенту від 23 жовтня 2007 р. «Оцінка і управління паводковими ризиками» [18], яка встановлює рамки сумісних дій держав в басейнах транскордонних річок в галузі водної політики (Рамкова Директива по воді WFD), а також в інших документах.

\section{2 Критеріальні показники оцінки паводкових ризиків}

Паводковий ризик - це ризик затоплення територій i шкідливого впливу паводку на умови проживання та діяльності людей в річковому басейні. Параметри паводкового ризику доцільно згрупувати за трьома узагальнюючими критеріальними (оціночними) показниками: інтенсивність паводку; зона затоплення; наслідки затоплення.

Серед критеріальних показників паводкового ризику визначальним показником $\epsilon$ інтенсивність паводку, оскільки від нього функціонально залежать два інших критеріальних показники паводкового ризику - зона затоплення і наслідки затоплення (втрата і збиток від паводку).

Інтенсивність паводку можна визначити різними способами, наприклад шляхом порівняння максимальної витрати води $Q_{\max }$ в розрахунковому створі русла річки в паводковий період і витрати води $Q_{\text {меж }}$ в меженний період. За першим способом інтенсивність паводку $\eta_{a}$ визначають через абсолютну величину перевищення витрати $Q_{\max }$ відносно меженної витрати $Q_{\text {меж: }}$ :

$$
\eta_{a}=Q_{\max }-Q_{\text {меж }} .
$$

Більш повну характеристику шкідливої дії паводку дає показник інтенсивності $\eta_{n}$, визначений за другим способом, у вигляді відношення витрати паводкового потоку води $Q_{\max }$ до витрати $Q_{\text {меж: }}$ :

$$
\eta_{n}=Q_{\text {max }} / Q_{\text {меж }} .
$$

У гідрології інтенсивність паводку прийнято визначати величиною його забезпеченості [19]. Для цього в кожному $m$-му році спостережень за минулий 
період враховують тільки максимальну за рік витрату води $Q_{m}$ в створі річки, яку розміщують в ряд (3) в порядку послідовного зменшення $Q_{m}$ :

$$
Q_{1} \geq Q_{2} \geq Q_{3} \geq \ldots \geq Q_{m} \geq \ldots \geq Q_{n-1} \geq Q_{n},
$$

де $m$ - порядковий номер року в ряду; $n$ - кількість років спостережень.

Забезпеченість паводку $p_{m}$ в $m$-му році визначають як ймовірність (у відсотках) перевищення витрати $Q$ води в річці значення $Q_{m}\left(Q>Q_{m}\right)$ за формулою [19]:

$$
p_{m}=\frac{m}{n+1} \cdot 100 \%
$$

За потреби класифікувати паводки за їх інтенсивністю поставимо задачу визначення кількості паводків певної забезпеченості $p$, що припадає на 100 років.

Припустимо, що маємо ряд емпіричних даних витрати води в створі річки у кожному році минулого періоду протягом 100 років:

$$
Q_{1} \geq Q_{2} \geq Q_{3} \geq \ldots \geq Q_{t} \geq \ldots \geq Q_{99} \geq Q_{100} .
$$

Забезпеченість паводку $p_{t}$ в кожному $t$-му році періоду часу у 100 років визначиться за формулою:

$$
p_{t}=\frac{t}{100+1} \cdot 100 \% \cong \frac{t}{100} \cdot 100 \%=t \cdot 1 \%
$$

У відповідності до ряду (5) результати розрахунку $p_{t}$ за формулою (6) представимо рядом (7):

$$
p_{1} \leq p_{2} \leq p_{3} \leq \ldots \leq p_{t} \leq \ldots \leq p_{99} \leq p_{100} .
$$

Отже, забезпеченість кожного наступного паводку ряду (7), порівняно 3 попереднім паводком, збільшується на $1 \%$. На періоді часу у 100 років в граничній точці $\left(t=100, p_{100}=100 \%\right)$ маємо 100 паводків, забезпеченість яких не перевищує $100 \%$, а в граничній точці $t=1, p_{1}=1 \%$ ) маємо 1 паводок, забезпеченість якого не перевищує $1 \%$.

Шляхом виділення на періоду часу у 100 років проміжних точок ряду (7) запропоновано класифікувати паводки за їх інтенсивністю (величиною забезпеченості) згідно з таблицею 1.

Оцінку паводків зазвичай виконують не за величиною їх забезпеченості $p_{t}$, розрахованою за формулою (6) при $n=100$, а за величиною забезпеченості $p_{m}$, розрахованою за формулою (4) при $n<100$. Оскільки визначені за формулами (4) i (6) величини забезпеченості паводків $p_{m}$ і $p_{t} \epsilon$ імовірнісними, вони при достатній кількості років спостережень $n$ не будуть суттєво відрізнятись. 
Таблиця 1 - Класифікація паводків за величиною їх забезпеченості

\begin{tabular}{|c|c|c|c|c|}
\hline $\begin{array}{c}\text { Забезпеченість } \\
\text { паводку } p, \%\end{array}$ & $\begin{array}{c}\text { Кількість } \\
\text { паводків } \\
\text { протягом } 100 \\
\text { років, } K_{100}\end{array}$ & $\begin{array}{c}\text { Імовірний період } \\
\text { повторення } \\
z_{p}=100 / K_{100,} \text { роки }\end{array}$ & $\begin{array}{c}\text { Клас } \\
\text { паводку }\end{array}$ & $\begin{array}{c}\text { Характерна } \\
\text { назва паводку }\end{array}$ \\
\hline 100 & 100 & $100 / 100=1$ & 1 & $\begin{array}{c}\text { Малий } \\
\text { (щорічний) }\end{array}$ \\
\hline 25 & 25 & $100 / 25=4$ & 2 & Середній \\
\hline 5 & 5 & $100 / 5=20$ & 3 & Великий \\
\hline 2 & 2 & $100 / 2=50$ & 4 & Катастрофічний \\
\hline 1 & 1 & $100 / 1=100$ & 5 & Видатний \\
\hline
\end{tabular}

Другим критеріальним показником паводкових ризиків є зона затоплення, яку визначають за такими параметрами: контур зони затоплення; площа затопленої території; максимальна та середня глибина затоплення в заплавах $\mathrm{i}$ долинах річки.

Третім критеріальним показником паводкових ризиків $\epsilon$ наслідки затоплення, або наслідки шкідливого впливу паводків на життєдіяльність людей в річкових басейнах. Наслідки затоплення визначають за величиною втрати від паводку, а також за розміром збитку від паводку.

Втрату від паводку в річковому басейні визначають за трьома іiі складовими: соціальна втрата - втрата життя та здоров'я людей, а також погіршення умов проживання населення внаслідок проходження паводку; екологічна втрата - втрата первинних якісних та кількісних властивостей навколишнього середовища і природних ресурсів; економічна втрата - втрата споживчих та функціональних властивостей об'єктів матеріально-виробничої сфери.

Під збитком від паводку розуміють оцінену у грошових одиницях втрату від паводку. Отже, відповідно до втрати від паводку, визначеної у фізичних величинах за соціальною, екологічною i економічною складовими, розраховують у грошових одиницях збиток від паводку за складовими: соціальний збиток, екологічний збиток і економічний збиток.

\section{3 Управління паводковими ризиками}

Запропоновано розрізняти два типи протипаводкового захисту: ситуаційний i превентивний, в зв'язку з чим протипаводкові заходи слід поділяти на ситуаційні і превентивні [20].

Ситуаційні протипаводкові заходи призначені для захисту території від певного фіксованого паводку, внаслідок якого на цій території виникає надзвичайна ситуація. Управління ситуаційними заходами передбачає короткострокове прогнозування паводків за гідрологічними показниками i можливим збитком 3 подальшим виконанням переважно службами надзвичайних ситуацій попереджувальних, аварійно-рятувальних та ремонтновідновлювальних заходів. До складу ситуаційних протипаводкових заходів входить: оповіщення населення; вивезення людей, тварин, коштовностей i готової продукції з території, до якої наближається паводок; термінове кріплення берегів річок і нарощування дамб; додаткове кріплення доріг, мостів, електромереж і засобів зв'язку; рятувальні, медичні та санітарно-епідеміологічні 
роботи; постачання населення продовольством, одягом і засобами, необхідними для виживання в екстремальних ситуаціях; роботи 3 відновлення споруд, локалізації та зупинки зсувів.

Превентивні протипаводкові заходи призначені для захисту територій в басейнах річок від багатьох паводків, які можуть відбуватись в майбутньому протягом досить тривалого періоду часу, який зазвичай відповідає строку служби захисних споруд. Превентивні протипаводкові заходи виконують шляхом довгострокового прогнозування паводків, проектування, будівництва та експлуатації інженерних споруд та систем захисту від паводків в річкових басейнах.

Відповідно до ділення протипаводкових заходів на ситуаційні і превентивні, управління паводковими ризиками також здійснюють за двома принципово відмінними альтернативними напрямами (варіантами): управління ситуаційними заходами і управління превентивними заходами. Загальна суміщена схема управління протипаводковими заходами наведена на рис. 2. У лівій частині схеми відображено управління ситуаційними протипаводковими заходами (рис. 1.2a), а у правій - превентивними протипаводковими заходами (рис. 1.26).

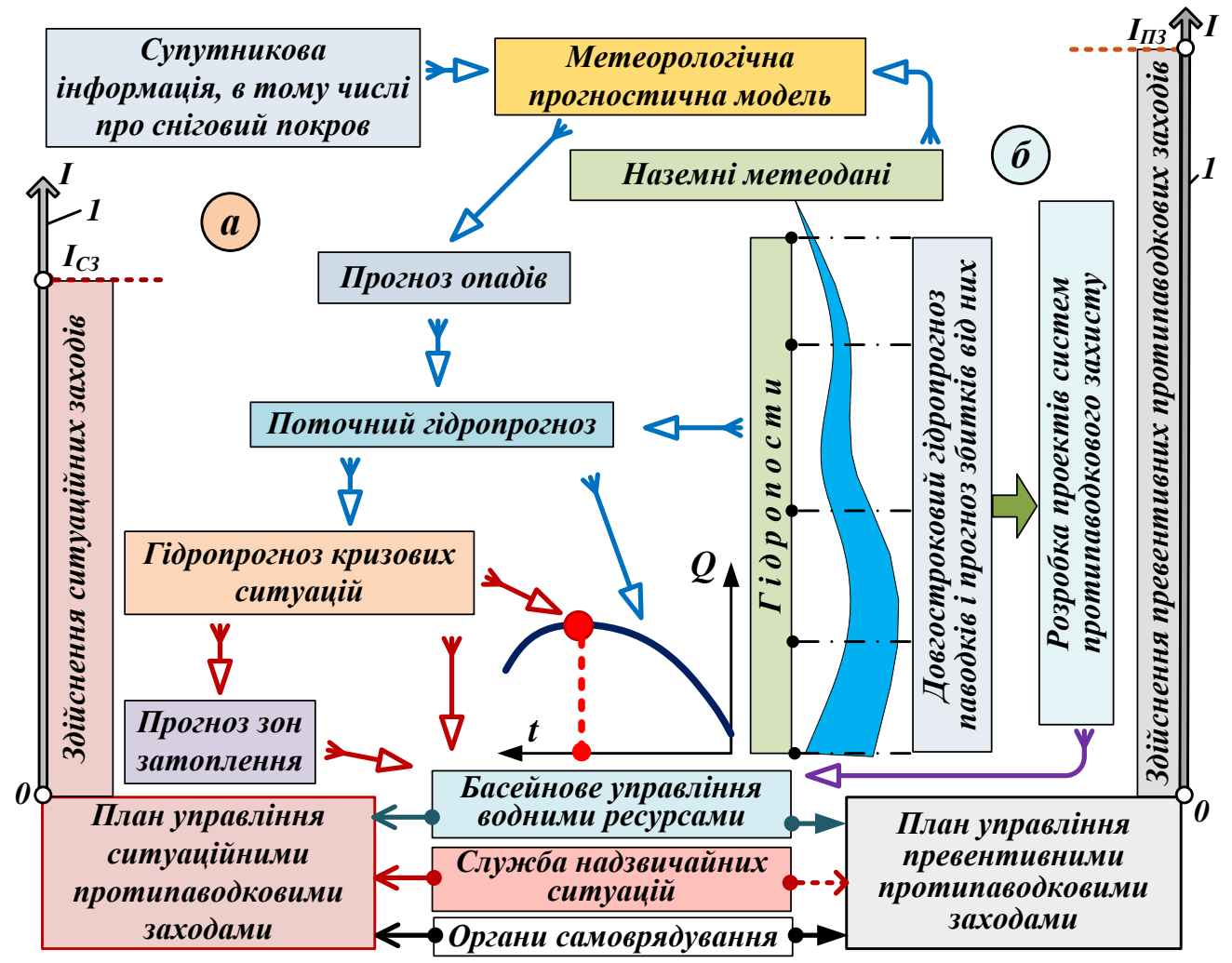

Рис. 2 - Схеми управління паводковими ризиками:

$a-$ управління ситуаційними протипаводковими заходами; $\sigma$ - управління превентивними протипаводковими заходами; 1 - вісь індексу ефективності протипаводкових заходів 
Прийняття управлінських рішень щодо застосування певного типу протипаводкового захисту (ситуаційного чи превентивного) запропоновано здійснювати за критерієм (цільовою функцією) досягнення найбільшої величини індексу I ефективності вкладення інвестицій у захисні заходи:

$$
I=\frac{B 3_{1}}{B_{1}+H B 3_{1}} \rightarrow \max
$$

де $B 3_{1}$ i $H B 3_{1}$ - середньорічна сума відвернених i не відвернених протипаводковими заходами збитків від паводків, тис. грн/рік; $B_{1}-$ середня сума витрат на виконання протипаводкових заходів протягом одного року, тис. грн/рік.

Вибір типу протипаводкового захисту здійснюють шляхом порівняння визначених за цільовою функцією (8) індексу $I_{C 3}$ ефективності вкладення інвестицій в ситуаційні протипаводкові заходи і індексу $I_{\Pi з}$ ефективності вкладення інвестицій в превентивні протипаводкові заходи. Якщо для певної території в басейні паводконебезпечної річки індекс $I_{C 3}$ буде вище індексу $I_{\Pi 3}$ $\left(I_{C 3}>I_{I 3}\right)$, то обирають варіант застосування ситуаційних заходів. Якщо ж навпаки $\left(I_{\Pi 3}>I_{C 3}\right)$, то для даної території слід обирати превентивні заходи. В басейнах річок Карпатського регіону найбільш ефективними є превентивні протипаводкові заходи. На територіях, де здійснено превентивний протипаводковий захист, необхідність здійснення ситуаційних заходів мінімальна, або вона зовсім відсутня.

\section{4 Короткострокове прогнозування паводків}

Ефективність здійснення ситуаційних протипаводкових заходів в значній мірі залежить від своєчасного реагування на паводок, що наближується. Інформацію про наближення паводку та його імовірну інтенсивність отримують шляхом короткострокового прогнозування із застосуванням різних методів. 3 гідрологічної точки зору короткострокове прогнозування паводків це один з видів гідрологічних прогнозів, за яким попередження наближення паводку можна отримати не більше, ніж за 12-15 діб до його настання. Методи короткострокового прогнозування базуються на використанні закономірностей руху води в руслах річок і закономірностей припливу (стоку) води на досліджуваних ділянках цих русел [21]. Основу короткострокового прогнозування складають розрахунки переміщення і трансформації водного потоку під час його проходження окремими ділянками русел. За результатами короткострокових прогнозів видається інформація про очікувані максимальні витрати і рівні води у вигляді гідрографів - залежності у часі витрати води.

Розрізняють ручні і автоматизовані методи контролю рівнів паводкових вод, які використовують програмне і апаратне забезпечення [9].

Ручні методи передбачають вимірювання з участю гідролога рівня води в певному створі русла річки за допомогою лінійок з подальшою передачею інформації у систему її обробки.

Автоматизовані методи контролю поділяють на прямі та дистанційні.

Прямі автоматизовані методи контролю рівня води здійснюють 3 використанням автоматизованих датчиків рівня води та автоматизованих вимірювальних станцій (рис. 3). 

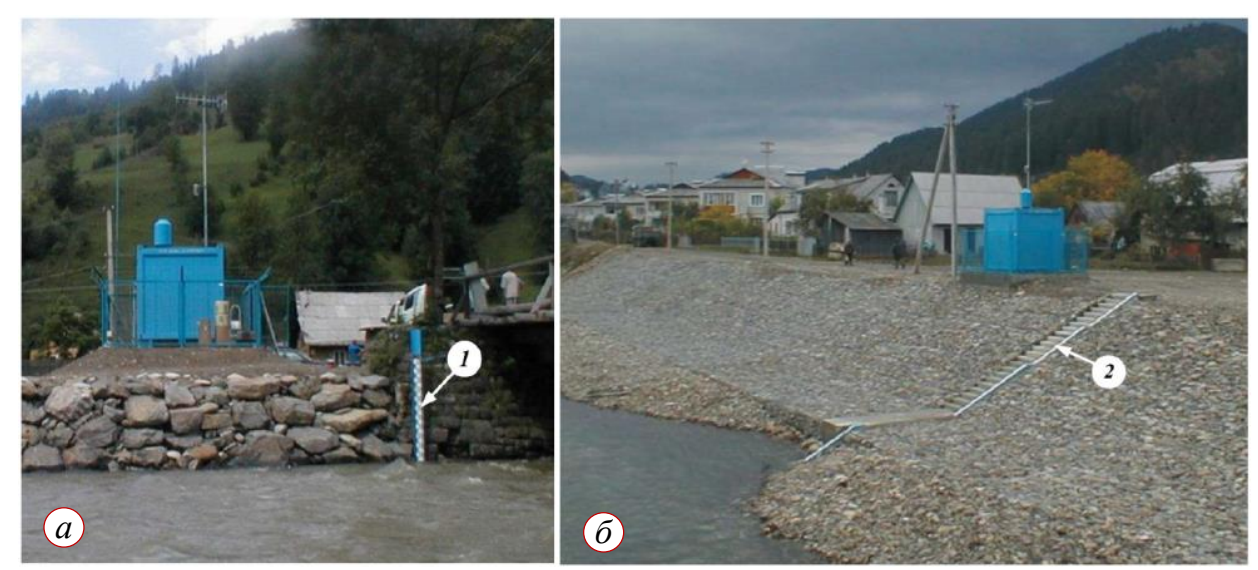

Рис. 3 - Автоматизовані вимірювальні станції інформаційно-вимірювальної системи «Тиса», призначеної для короткострокового прогнозу паводків в басейні р. Тиса на Закарпатті [22]: $a$ - на р. Біла Тиса у с. Луги; $\sigma$ - на р. Ріка у смт Міжгір'я; 1 - водомірна рейка вертикальна; 2 - водомірна рейка похила

У Басейновому управлінні водних ресурсів річки Тиса впроваджена автоматизована інформаційно-вимірювальна система (AIBC) «Тиса» [22], яка призначена для:

- оперативного прогнозування гідрографів паводків на ріках басейну за допомогою спеціального математичного, інформаційного і програмного забезпечення;

- підготовки достовірної прогнозної інформації про параметри паводку і передачі іiі в автоматичному режимі відповідним службам оповіщення і протипаводковим підрозділам;

- видачі рекомендацій для прийняття рішень щодо безаварійного пропуску паводків.

Зараз знаходиться на стадії розробки і впровадження інформаційновимірювальна система «Прикарпаття». Основне призначення системи прогнозування розвитку паводків в басейнах річок Дністер, Прут і Серет на території семи областей: Чернівецької, Івано-Франківської, Львівської, Вінницької, Тернопільської, Хмельницької та Одеської. Система здійснює прогнозування розвитку паводків, автоматизоване спостереження за опадами, рівнями води в річках, передачу інформації в режимі реального часу в центри обробки інформації для своєчасного оповіщення населення та прийняття заходів реагування [9].

До дистанційних методів вимірювання належать методи вимірювання рівнів води із застосуванням засобів авіації (літаки, гелікоптери), а також космічних (супутникових) систем.

В процесі короткострокового прогнозування паводків результати контролю рівнів води ручними чи автоматичними методами потребують певної математичної обробки. Для цього використовують:

- інноваційний алгоритм поділення зображення на класи «суходіл»/«вода», який базується на концепції нечітких множин та використанні міри когерентності [23];

- нейромережевий метод картографування паводків на основі супутникових зображень [24]; 
- метод оперативного прогнозування паводків за даними наземних i радіолокаційних вимірювань опадів, за яким забезпечується можливість обробити інформацію про опади на великій площі [9].

\section{5 Довгострокове прогнозування паводків}

Довгострокове прогнозування паводків зазвичай виконують для передбачення масштабів дії паводків у майбутньому та оцінки ефективності проектів систем превентивного протипаводкового захисту в річкових басейнах.

Методики довгострокового прогнозування паводків базуються на визначенні максимальних витрат води в руслах і кількості паводків певної забезпеченості, а також можливих збитків від паводків в басейнах річок на періоді часу, що відповідає строку експлуатації протипаводкових систем (30-50 років). Слід відзначити недосконалість відомих методик довгострокового прогнозування. Так, наприклад, за методикою нечіткого прогнозування очікуваних збитків від паводків на основі екстраполяцій кінцевим результатом прогнозування $\epsilon$ математично формалізовані нечіткі множини, які через недостатню детермінацію потребують використання експертних оцінок [9, 25].

Пропонується методика довгострокового прогнозування паводків, в основу якої покладено незмінність тенденції (тренду) розвитку паводкових ситуацій в річкових басейнах протягом певного періоду, що охоплює як минулі, так i майбутні роки. Використання даної методики вимагає наявності належного архіву спостережень під час проходження паводків минулих років та його постійного ведення у майбутньому службами гідрології та надзвичайних ситуацій.

Довгострокове прогнозування паводків виконують поетапно, використовуючи інформацію про результати спостережень паводків, які після іiі обробки зводять у таблицю 2 .

Таблиця 2 - Зведення результатів спостережень проходження паводків за минулий період

\begin{tabular}{|c|c|c|c|c|c|c|c|c|c|}
\hline \multirow{2}{*}{$\begin{array}{c}\text { Критеріальні } \\
\text { показники }\end{array}$} & \multicolumn{3}{|c|}{ Параметри } & \multicolumn{5}{|c|}{ Роки спостережень } & \multirow{2}{*}{$\begin{array}{c}\text { № } \\
\text { рядка }\end{array}$} \\
\hline & \multicolumn{2}{|c|}{ Назва } & Од. виміру & 1 & $\ldots$ & $m$ & .. & $n$ & \\
\hline \multirow{2}{*}{$\begin{array}{c}\text { Інтенсивність } \\
\text { паводку } \\
\end{array}$} & \multicolumn{2}{|c|}{ Витрата води } & $\mathrm{M}^{3} / \mathrm{c}$ & $Q_{1}$ & & $Q_{m}$ & & $Q_{n}$ & 1 \\
\hline & \multicolumn{2}{|c|}{ Забезпеченість паводку } & $\%$ & $p_{1}$ & 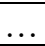 & $p_{m}$ & & $p_{n}$ & 2 \\
\hline \multirow{4}{*}{$\begin{array}{c}\text { Зона } \\
\text { затоплення }\end{array}$} & \multicolumn{2}{|c|}{ Контур зони затоплення } & $\begin{array}{c}*_{3} \text { згідно } \\
\text { зі схемою }\end{array}$ & $*$ & $\ldots$ & $*$ & $\ldots$ & $*$ & 3 \\
\hline & \begin{tabular}{|l|} 
Площа \\
території
\end{tabular} & затопленої & тис. $\mathrm{m}^{2}$ & $S_{1}$ & $\ldots$ & $S_{m}$ & $\ldots$ & $S_{n}$ & 4 \\
\hline & \multirow{2}{*}{\begin{tabular}{|l|} 
Глибина \\
затоплення
\end{tabular}} & максимальна & M & $h_{l}^{\max }$ & $\ldots$ & $h_{m}^{\max }$ &. & $h_{n}^{\max }$ & 5 \\
\hline & & середня & M & $h_{l}^{c p}$ & $\ldots$ & $h_{m}^{c p}$ & $\ldots$ & $h_{n}^{c p}$ & 6 \\
\hline \multirow{8}{*}{$\begin{array}{c}\text { Наслідки } \\
\text { затоплення }\end{array}$} & \multirow{4}{*}{$\begin{array}{l}\text { Втрата від } \\
\text { паводку }\end{array}$} & соціальна & \multirow{4}{*}{ 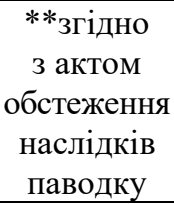 } & $* *$ & $\ldots$ & $* *$ & $\ldots$ & $* *$ & 7 \\
\hline & & екологічна & & $* *$ & $\ldots$ & $* *$ & $\ldots$ & $* *$ & 8 \\
\hline & & економічна & & $* *$ & $\ldots$ & $* *$ & $\ldots$ & $* *$ & 9 \\
\hline & & загальна & & ** & $\ldots$ & ** & $\ldots$ & ** & 10 \\
\hline & \multirow{4}{*}{$\begin{array}{l}\text { Збиток від } \\
\text { паводку }\end{array}$} & соціальний & \multirow{4}{*}{ тис. грн/рік } & $3_{11} \mathrm{Cu}$ & $\cdots$ & $3_{1 m}{ }^{C u}$ & & $3{ }_{\ln }^{C u}$ & 11 \\
\hline & & екологічний & & 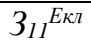 & $\ldots$ & 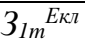 & $\ldots$ & $3_{\ln }^{E \kappa \pi}$ & 12 \\
\hline & & економічний & & $3_{11}^{\text {ЕкH }}$ & $\ldots$ & $3_{1 m}^{\text {ЕкH }}$ & $\cdots$ & $3_{\ln }^{\text {EKH }}$ & 13 \\
\hline & & загальний & & $3_{11}$ & $\ldots$ & $3_{I m}$ & $\ldots$ & 3 & 14 \\
\hline
\end{tabular}


Етап 1. «Визначення розрахункового (критеріального) створу річки».

Розрахунковим вважають створ річки, в якому динаміка зміни гідрологічних показників найбільш точно відображає динаміку зміни параметрів зони затоплення 3 (рис. 4) і наслідків проходження паводку. Розрахунковий створ можна вважати ще й критеріальним, оскільки витрата $Q_{m}$ паводкового потоку в ньому $є$ гідрологічним критерієм оцінки паводку, від якого залежать інші критеріальні показники паводку: зона затоплення і наслідки затоплення в басейні річки у $m$-му році. Розрахунковий створ обирають в одному з найближче розташованих до зони затоплення створів, обладнаних гідрологічним постом. Розрахунковим може бути створ річки як на початку (поз. 7 на рис. 4), так і в кінці (поз. 8 на рис. 4) зони затоплення 3. При цьому периметр контуру зони затоплення $\epsilon$ варійованим і залежить від забезпеченості паводку. Мінімальна зона затоплення 3 контуром 4 утворюється внаслідок проходження щорічного весняного паводку забезпеченості $p_{\max }=100 \%$. Максимальна зона затоплення 3 контуром 5 утворюється внаслідок проходження найбільш інтенсивного паводку забезпеченості $p_{\min }$ (рис. 4). Вибір розрахункового створу річки здійснюють залежно від характеру припливу паводкових вод до зони затоплення. Якщо приплив паводкових вод до зони затоплення 3 відбувається тільки через русло річки 1 , яка не має притоки 2, розрахунковим вважають створ 7. Якщо приплив паводкових вод до зони затоплення відбувається як через русло річки 1 , так і через русло притоки 2, розрахунковим вважають створ 8 (рис. 4). У будь-якому разі з двох створів (7 або 8) за розрахунковий обирають створ, у якому витрата води більша.

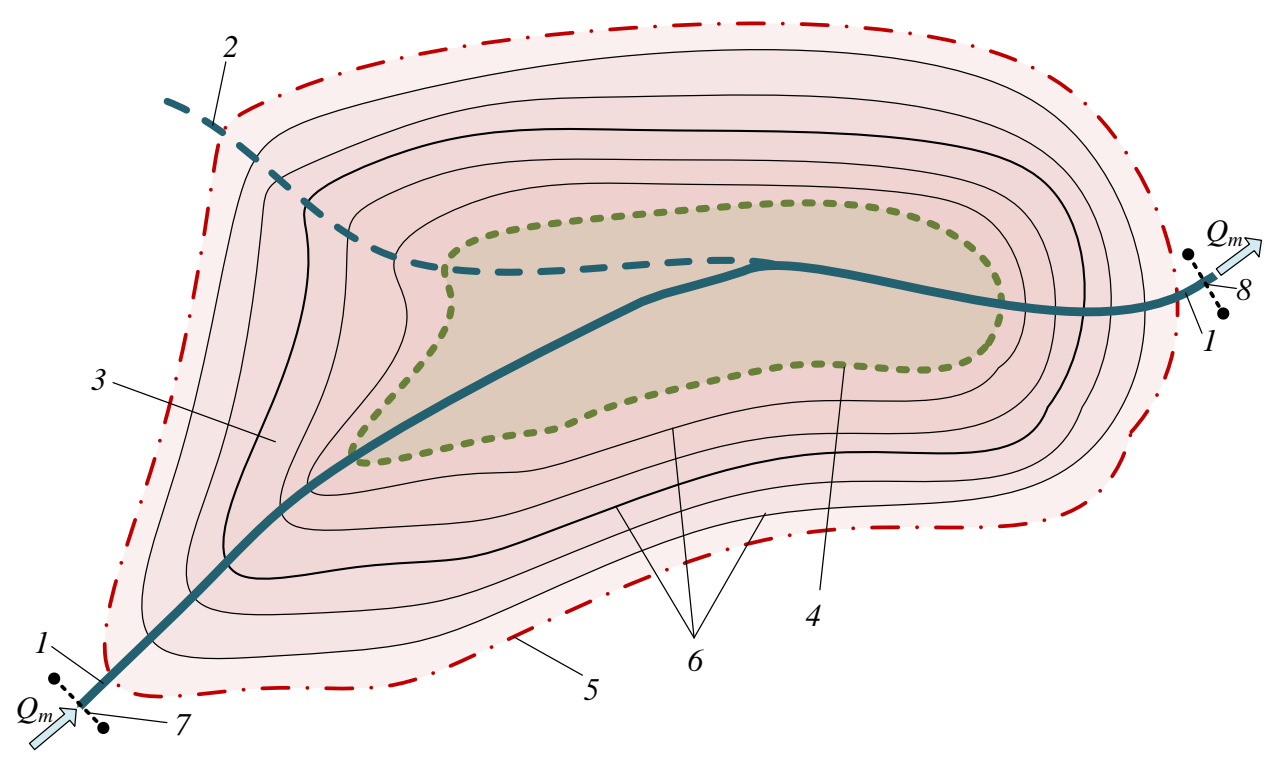

Рис. 4 - Схема затопленої території, залежно від інтенсивності паводку:

1 - річка; 2 - притока річки; 3 - зона затоплення з варійованим контуром залежним від забезпеченості паводку; 4 - контур зони затоплення щорічним весняним паводком забезпеченості $p_{\max }=100 \% ; 5$ - контур зони затоплення найбільш інтенсивним паводком забезпеченості $p_{\min } ; 6$ - контур зони затоплення, залежний від забезпеченості паводку $p\left(p_{\max }>p>p_{\min }\right) ; 7$ - розрахунковий створ русла річки, якщо іiї притоки впадають в річку поза зоною затоплення; 8 - розрахунковий створ русла річки, якщо притоки впадають в річку в зоні затоплення 
Етап 2. «Аналіз та обробка результатів гідрологічних досліджень паводків за минулий період».

Визначають інтенсивність паводків за $n$ років спостережень минулого періоду. Для цього ряд (3) результатів вимірювань витрати води $Q_{m}$ у розрахунковому створі річки заносять до рядка 1 таблиці 2. Результати розрахунків за формулою (4) забезпеченості паводків заносять до рядка 2 таблиці 2. За експериментальними точками $\left(Q_{m}, p_{m}\right)$ рядків 1 і 2 таблиці 2 будують емпіричну криву 2 залежності $Q(p)$ (рис. 5).

Зваживши на недостатню кількість емпіричних точок 1 (рис. 5) та можливі похибки їх визначення, результати гідрологічних вимірювань згладжують, замінюючи емпіричну криву 2 теоретичною кривою 3. Теоретична крива $3 \epsilon$ графіком спадної функції $Q=f_{l}(p)$, яку можна представити гіперболою такого виду:

$$
Q=\frac{k_{1}}{p}+k_{2}
$$

Для обробки емпіричних точок $\left(Q_{m}, p_{m}\right)$ за методом найменших квадратів доцільно позначити: $1 / p=x ; 1 / p_{m}=x_{m}$. Це дає можливість замінити гіперболічну функцію (9) лінійною функцією (10):

$$
Q=f_{1}(x)=k_{1} x+k_{2} .
$$

Для визначення невідомих коефіцієнтів $k_{1}$ i $k_{2}$ функції (10) складають функцію неузгодженості $\Phi\left(k_{1}, k_{2}\right)$ та знаходять їі мінімальне значення:

$$
\Phi\left(k_{1}, k_{2}\right)=\sum_{m=1}^{n}\left(Q_{m}-\left(k_{1} x_{m}+k_{2}\right)\right)^{2} \rightarrow \text { min }
$$

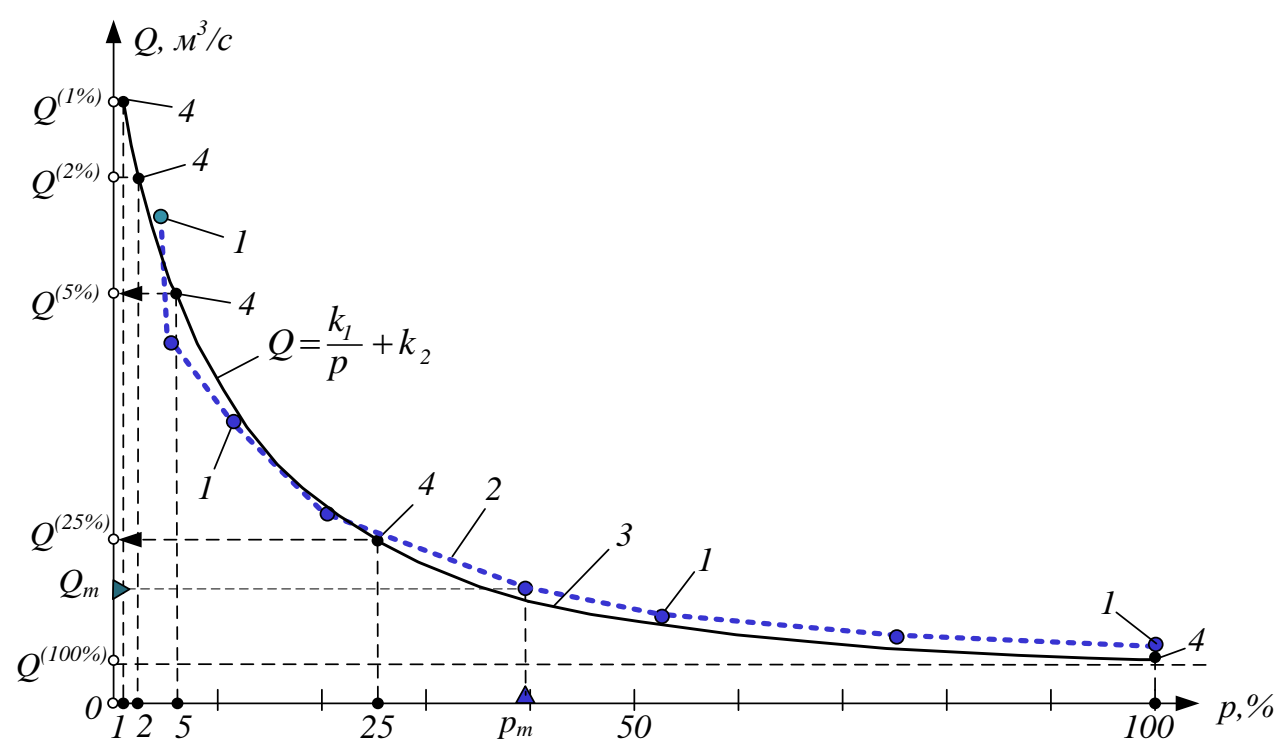

Рис. 5 - Результати гідрологічних досліджень в розрахунковому створі русла річки: 1 - емпіричні точки $\left(Q_{m}, p_{m}\right) ; 2$ - емпірична крива $Q(p) ; 3$ - теоретична крива $Q=f_{1}(p)$;

4 - точки на теоретичній кривій, що відповідають п’ятьом встановленим класам паводків 
Після математичних перетворень невідомі коефіцієнти $k_{1}$ i $k_{2}$ лінійної функції (10), а отже і гіперболічної функції (9), знаходять з системи рівнянь:

$$
\left\{\begin{array}{c}
k_{1}=\frac{n \sum_{m=1}^{n} x_{m} Q_{m}-\sum_{m=1}^{n} x_{m} \cdot \sum_{m=1}^{n} Q_{m}}{n \sum_{m=1}^{n} x_{m}^{2}-\left(\sum_{m=1}^{n} x_{m}\right)^{2}} \\
k_{2}=\frac{\sum_{m=1}^{n} Q_{m}-k_{1} \sum_{m=1}^{n} x_{m}}{n}
\end{array} .\right.
$$

Встановивши значення $k_{l}$ і $k_{2} 3$ (12) по розрахункових точках, основними 3 яких є точки 4, що відповідають п'ятьом виділеним класам паводків, будують теоретичну криву 3 функції (9).

Етап 3. «Аналіз та обробка емпіричних даних наслідків проходження паводків за минулий період».

Використовуючи дані спостережень проходження паводків в річковому басейні, визначають параметри зони затоплення у минулих роках: контур зони затоплення; площу затопленої території; максимальну і середню глибину затоплення. Ці параметри заносять до рядків 3-6 таблиці 2.

Потім для зони затоплення у кожному році спостережень визначають наслідки - втрату і збиток від паводків. Втрату від паводку визначають у фізичних показниках згідно 3 актами обстеження наслідків проходження паводку за складовими: соціальна, екологічна, економічна і загальна втрата.

До соціальних аспектів втрати від паводку відносять: втрату життя та здоров'я населення; втрату, пов'язану з порушенням постачання населення продовольчими та промисловими товарами внаслідок ускладнення транспортних перевезень; втрату комфортних умов проживання населення; втрату можливості потрапити на роботу; втрату можливості здійснення особистих планів людей тощо.

До екологічних аспектів втрати від паводку відносять втрату первинних якісних та кількісних властивостей: навколишнього середовища (гідросфера, літосфера, рослини, тварини); природних ресурсів (земельних, водних, лісових та інших); природно-охоронних зон (рекреаційних, заповідних).

До економічних втрат від паводку відносять втрати підприємств та господарств: основних фондів; обігових фондів; готової промислової продукції; сільськогосподарської продукції; худоби тощо.

Загальну втрату від паводків минулого періоду за іiі складовими фіксують у рядках 7-10 таблиці 2.

Довгострокове прогнозування здійснюють за розміром загальних збитків від паводків, що можуть відбутись у майбутньому. Загальний збиток від кожного паводку $m$-го року минулого періоду визначають за його складовими:

$$
3_{1 m}=3_{1 m}{ }^{c u}+3_{1 m}{ }^{\text {eкr }}+3_{1 m}{ }^{\text {eкH }},
$$


де $33_{1 m}-$ збиток від паводку загальний, тис. грн/рік; $3_{1 m}{ }^{c u}, 3_{1 m}{ }^{\text {екл }}$ i $3_{1 m}{ }^{\text {екн }}-$ збиток від паводку соціальний, екологічний і економічний, тис. грн/рік.

Соціальний, екологічний, економічний i загальний збиток від паводку визначають у грошових одиницях в індексах цін на момент виконання процедури довгострокового прогнозування паводків. Для розрахунку загального збитку від паводку $3_{l m}$ використовують два методичних підходи, які обирають залежно від попередньо визначеної у $m$-му році інформації про паводок.

Якщо у $m$-му році був встановлений загальний збиток від паводку в цінах $m$-го року, то загальний збиток за всіма його складовими визначають шляхом дисконтування за формулою:

$$
3_{1 m} \leftrightarrow 3_{1 m}^{\tau}=3_{1 m}^{m}(1+\varepsilon)^{(\tau-m)},
$$

де $\tau$ - індекс року виконання довгострокового прогнозування або розробки проекту превентивного протипаводкового захисту; $3_{1 m}\left(3_{1 m}{ }^{2}\right)$ - загальний збиток від паводку, оцінений на момент часу довгострокового прогнозування, тис. грн/рік; $3{ }_{1 m}^{m}$ - загальний збиток від паводку, який був оцінений у минулому $m$-му році, тис. грн/рік; $\varepsilon$ - коефіцієнт дисконтування; $(\tau-m)-$ проміжок часу від минулого $m$-го до розрахункового $\tau$-го року, рік.

Якщо у $m$-му році не було встановлено величину загального збитку від паводку, або ця величина була визначена орієнтовно з певними похибками, проте фізичні показники наслідків (втрати від паводку) були зафіксовані 3 достатньою точністю, то складові загального збитку від паводків доцільно розраховувати за величиною втрат від паводку, користуючись методиками $[26,27]$.

Величини збитків від паводків минулих років заносять до рядків 11-14 таблиці 2. За даними рядків 2 і 14 таблиці 2, отримують ряд (15) емпіричних точок $\left(3_{1 m}, p_{m}\right)$ :

$$
\left(3_{11}, p_{1}\right),\left(3_{12}, p_{2}\right), \ldots,\left(3_{1 m}, p_{m}\right), \ldots,\left(3_{1(n-1)}, p_{n-1}\right),\left(3_{1 n}, p_{n}\right) .
$$

За емпіричними точками ряду (15) будують емпіричну криву 2 залежності $3_{l}(p)$ (рис. 6).

Використовуючи емпіричні точки ряду (15), за методом найменших квадратів визначають теоретичну залежність загальних збитків $3_{1}$ від забезпеченості паводків у вигляді функції $3_{l}=f_{2}(p)$, яку також, як і функцію витрат води $Q=f_{l}(p)$, вважають спадною гіперболічною функцією:

$$
3_{1}=\frac{k_{3}}{p}+k_{4} \text {. }
$$

Невідомі коефіцієнти $k_{3}$ і $k_{4}$ функції (16) знаходять за методом найменших квадратів за тією ж процедурою, за якою були визначені коефіцієнти $k_{1}$ i $k_{2}$ функції (9).

Прогнозування загальних збитків від паводків 31 у вигляді гіперболічної функції (16) дає змогу, використовуючи статистичні дані відносно невеликої кількості паводків минулого періоду, визначати збитки від будь-яких можливих паводків майбутнього періоду за величиною їх забезпеченості. 


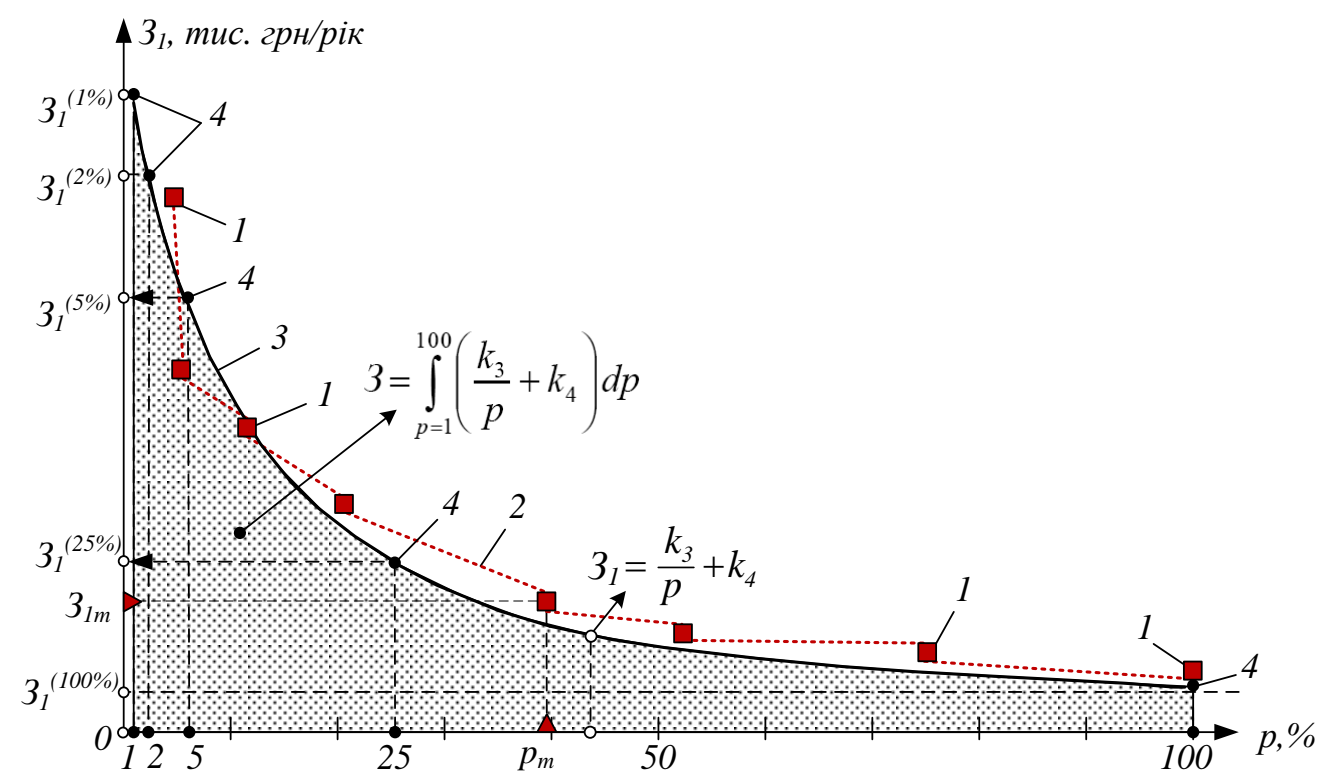

Рис. 6 - Результати досліджень збитків від паводків в зоні затоплення:

1 - емпіричні точки $\left(3_{1 m}, p_{m}\right) ; 2$ - емпірична крива $3_{1}(p) ; 3$ - теоретична крива $3_{1}=f_{2}(p)$;

4 - точки на теоретичній кривій, що відповідають п'ятьом встановленим класам паводків

Етап 4. «Визначення середньорічних збитків від паводків в зоні затоплення».

Обраний період часу довгострокового прогнозування $(t=1 \ldots 100$ років) відповідає діапазону зміни величини забезпеченості паводків ( $p=1 \ldots 100 \%)$. Це дає змогу визначити загальний прогнозований збиток в зоні затоплення шляхом інтегрування функції $3_{l}$ по аргументу $p$ :

$$
3_{T}=\int_{p=1}^{100}\left(\frac{k_{3}}{p}+k_{4}\right) d p=\left.\left(k_{3} \ln p+k_{4} p\right)\right|_{1} ^{100}=k_{3} \ln 100+k_{4} 99
$$

де $3_{T}$ - загальна величина збитків протягом розрахункового періоду $T$ від можливих паводків різних класів інтенсивності - від особливо видатного $(p=1 \%)$ до малого $(p=100 \%)$, тис. грн.

Наукова обгрунтованість методичного підходу визначення прогнозованої величини збитків від паводків шляхом інтегрування за формулою (17) підтверджується дотриманням в процесі інтегрування основного принципу дослідження паводків, прийнятого в гідрології [19], а саме, врахуванням протягом одного року тільки одного найбільш інтенсивного паводку.

Нижньою межею інтегрування обрано забезпеченість паводку $p=1$, тому відповідно до цього в розрахунках збитків від паводків перший рік $(t=1) 3$ загального періоду часу довгострокового прогнозування $(T=100)$ вилучають. Отже, середньорічний збиток від паводку протягом періоду часу довгострокового прогнозування визначають за формулою: 


$$
\begin{gathered}
\sim 35 \sim \\
{\left[3_{1}\right]=\frac{3_{T}}{T-1}=\frac{k_{3} \ln 100}{99}+k_{4},}
\end{gathered}
$$

де $\left[3_{l}\right]$ - середньорічний збиток від паводку в зоні затоплення, тис. грн/рік.

Етап 5. «Очінка ефективності заходів превентивного протипаводкового захисту».

Забезпеченість паводків, що спостерігались в Україні у минулих роках, зазвичай знаходилась в межах $1 \% \leq p \leq 100 \%$. Тому для досягнення надійного превентивного протипаводкового захисту зон затоплення проекти захисних споруд розроблюють на паводок розрахункової забезпеченості $p_{p}=1 \%$.

Позитивний ефект здійснення заходів превентивного протипаводкового захисту оцінюють розміром в зоні затоплення відвернених (протипаводковими заходами) збитків: $B 3_{l}, B 3_{T},\left[B 3_{1}\right]$ і $B 3_{C}$.

$B 3_{1}-$ річний відвернений збиток, який за величиною дорівнює збитку $3_{1} \mathrm{i}$ тому може бути розрахований за формулою (16).

$B 3_{T}$ - збитки, що будуть відвернені протягом розрахункового періоду $T$ довгострокового прогнозування. Відвернені збитки $B 3_{T}$ за величиною дорівнюють збиткам $3_{T}$ i можуть бути розраховані шляхом інтегрування за формулою (17).

$\left[B 3_{1}\right]$ - середньорічний відвернений збиток, який за величиною дорівнює збитку [3 $]$ і може бути розрахований за формулою (18).

$B 3_{C}$ - відвернені збитки, що очікуються протягом розрахункового строку експлуатації захисних протипаводкових споруд. Відвернені збитки $B 3_{C}$ розраховують за формулою:

$$
B 3_{C}=\left[B 3_{1}\right] T_{C}=\left(\frac{B 3_{T}}{T-1}\right) T_{C}=\left(\frac{k_{3} \ln 100}{99}+k_{4}\right) T_{C},
$$

де $T_{C}$ - розрахунковий строк експлуатації захисних протипаводкових споруд, рік.

Економічний ефект здійснення превентивних протипаводкових заходів визначають за формулою:

$$
E=B 3_{C}-\left(K_{C}+b_{e} T_{C}\right)
$$

де $K_{C}-$ капіталовкладення у будівництво протипаводкових споруд, тис. грн; $b_{e}$ - річні витрати, пов'язані з утриманням та експлуатацією споруд, тис. грн/рік.

Річний економічний ефект превентивних протипаводкових заходів визначають за формулою:

$$
E 1=E / T_{C}=\left[B 3_{1}\right]-\left(K_{C} / T_{C}+b_{e}\right) .
$$

Індекс ефективності $I_{П 3}$ вкладення інвестицій у превентивні протипаводкові заходи в кінці розрахункового строку $T_{C}$ експлуатації захисних протипаводкових споруд визначають за формулою: 


$$
I_{\Pi 3}=\frac{B 3_{C}}{K_{C}+b_{e} T_{C}} .
$$

Для визначення строку окупності інвестицій у превентивні протипаводкові заходи індекс ефективності $I_{t}$ вкладення інвестицій визначають функцією по аргументу $t\left(1 \leq t \leq T_{C}\right)$ :

$$
I_{t}=\frac{\left[B 3_{1}\right] t}{K_{C}+b_{e} t} .
$$

Окупність інвестицій у протипаводкові заходи досягається за умови: $I_{t}=1$;

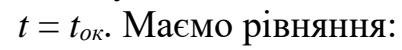

$$
1=\frac{\left[B 3_{1}\right] t_{\text {oк }}}{K_{C}+b_{e} t_{\text {oK }}} .
$$

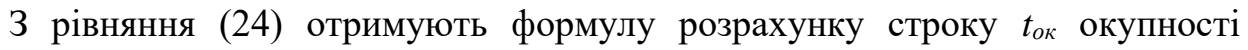
інвестицій:

$$
t_{\text {oK }}=\frac{K_{C}}{\frac{k_{3} \ln 100}{99}+k_{4}-b_{e}}=\frac{K_{C}}{0,0465 k_{3}+k_{4}-b_{e}}
$$

\section{Висновки}

1. В Україні, незважаючи на загальний дефіцит водних ресурсів, існує проблема паводків, яка в Карпатському регіоні має особливо небезпечний характер, що підтверджується статистикою паводкових ситуацій за минулий період, починаючи з кінця XIX століття.

2. Проблема паводків в Україні зумовлена двома головними чинниками нерівномірністю розподілу річкового стоку по території країни i нерівномірністю випадання опадів протягом року.

3. Залежно від інтенсивності паводків, визначеної за величиною їх забезпеченості, запропоновано розрізняти п'ять класів паводків: малі; середні; великі; катастрофічні і видатні.

4. Виділено два основних типи протипаводкового захисту - ситуаційний $\mathrm{i}$ превентивний, в зв'язку з чим протипаводкові заходи поділено на ситуаційні і превентивні.

5. Управління протипаводковим захистом ситуаційного типу передбачає короткострокове (менше 12-15 днів) прогнозування паводку і наступне реагування на нього шляхом послідовного виконання: попереджувальних заходів в період наближення паводку; аварійно-рятувальних заходів в період проходження паводку; аварійно-відновлювальних заходів після проходження паводку.

6. Управління протипаводковим захистом превентивного типу передбачає довгострокове з завчасністю до 100 років прогнозування паводків та наступне 
здійснення протипаводкових заходів шляхом будівництва і експлуатації протипаводкових споруд в басейнах паводконебезпечних річок.

7. Оцінку паводкових ризиків запропоновано здійснювати за гідрологічними показниками припливу паводкових вод i їх витоку із зони затоплення, а також за показниками соціальних, екологічних і економічних наслідків в зоні затоплення.

8. Основним показником наслідків проходження паводку встановлено загальний збиток, який запропоновано визначати у вигляді суми соціального, екологічного i економічного збитків, розрахованих за відповідними методиками у грошових одиницях.

9. Прийняття управлінських рішень щодо здійснення в басейні паводконебезпечної річки ситуаційного чи превентивного типу протипаводкового захисту запропоновано здійснювати за величиною індексу ефективності інвестицій, який представлено у вигляді відношення суми відвернених збитків до суми інвестиційних витрат на здійснення протипаводкових заходів.

10. Наголошено про відсутність досконалих методів довгострокового прогнозування паводків, в зв'язку з чим розроблено та запропоновано для науково-практичного використання методику, в основу якої покладено незмінність тенденції (тренду) розвитку паводкових ситуацій в річкових басейнах протягом періоду часу, що охоплює як минулі, так і майбутні роки.

11. Довгострокове прогнозування паводкових ризиків за гідрологічними показниками запропоновано здійснювати шляхом апроксимації результатів гідрологічних спостережень за минулі роки спадною гіперболічною функцією максимальних у кожному році витрат паводкових потоків по аргументу забезпеченості паводків на інтервалі від 1\% до 100\%.

12. Довгострокове прогнозування паводкових ризиків за показниками наслідків від паводків запропоновано здійснювати шляхом аналізу статистичних даних соціальних, екологічних і економічних наслідків від паводків за минулі роки та апроксимації загального збитку від паводків спадною гіперболічною функцією по аргументу забезпеченості паводків на інтервалі від 1\% до 100\%.

13. Основним розрахунковим показником довгострокового прогнозування паводкових ризиків визначено прогнозовану суму загальних збитків від паводків на майбутні 99 років, яку запропоновано визначати шляхом інтегрування гіперболічної функції загального збитку від паводків.

14. Показниками захисного протипаводкового ефекту превентивних заходів визначено: суму загальних відвернених збитків протягом майбутніх 99 років; середньорічний відвернений збиток; суму загальних відвернених збитків протягом розрахункового строку експлуатації захисних споруд.

15. Основним показником ефективності протипаводкового захисту превентивного типу обрано індекс ефективності інвестицій, який запропоновано визначати діленням відвернених збитків, що очікуються в кінці розрахункового строку експлуатації захисних споруд, на суму вкладених у протипаводковий захист інвестицій, строк окупності яких визначають періодом часу експлуатації споруд, за який загальна сума відвернених збитків буде дорівнювати сумі вкладених інвестицій. 


\section{СПИСОК ЛІТЕРАТУРИ}

1. StatInfo.biz - Международная экономическая статистика [Электронный ресурс]: Режим доступа: http://statinfo.biz/Data.aspx?act=6467\&lang=1 .

2. Петроченко А. В. Проблема дефицита воды и паводков в Украине / А. В. Петроченко // Пути повышения эффективности орошаемого земледелия / ФГБНУ «РосНИИПМ»- Новочеркасск: РосНИИПМ, 2018 - Вып. 3(71). - С. 133-140.

3. Сусідко М.М. Районування території України за ступенем гідрологічної небезпеки / М.M. Сусідко, О.І. Лук’янець // Наук. праці УкрНДГМІ. - 2004. - Вип. 253. C. 196-202.

4. Алексеев Н.А. Стихийные явления в природе: проявление, эффективность защиты / Н.А. Алексеев. - М.: Мысль, 1988. - 254 с.

5. Нежиховский Р.А. Наводнения на реках и озерах / Р.А. Нежиховский. - Л.: Гидрометеоиздат, 1988. - $184 \mathrm{c.}$

6. Швец Г.И. Выдающиеся гидрологические явления на юго-западе СССР / Г.И. Швец. - Л.: Гидрометеоиздат, 1972. - 512 с.

7. Козьменко С.Н. Экономика катастроф (инвестиционные аспекты) / С.Н. Козьменко. - Киев: Наукова думка. - 1997. - 2004 с.

8. Протипаводковий захист. Інформаційно-аналітична довідка щодо проблем комплексного протипаводкового захисту територій регіонів України від катастрофічних паводків та мінімізації збитків від шкідливої дії вод [Електронний pecypc] : Протипаводковий захист / Державне агентство водних ресурсів України. Офіційний сайт. - Режим доступу: http://www.scwm.gov.ua/index.php.

9. Заміховський Л.М. Аналіз методів і систем контролю та прогнозування рівня паводкових вод / Л.М. Заміховський, О.І Клапоущак // Нафтогазова енергетика. - 2011. - №2(15). - С. 99-105.

10. Перехрест С.М. Шкідливі стихійні явища в Українських Карпатах та засоби боротьби з ними / С.М. Перехрест, С.Г. Кочубей, О.М. Пєчковська. - Київ: Наукова думка, 1971. - 200 с.

11. Савчук Д. П. Особливості повеней, паводків та захисту від них у Карпатському регіоні / Д.П. Савчук // Водне господарство України. - 2010. - № 5. - С. 46-49.

12. Карпенко Ю.О. Топоніміка Буковини / Ю.О. Карпенко. - Київ: Наукова думка, 1973. -238 c.

13. Беднарчик Л.І. Аналіз змін паводкового режиму р. Серет в межах Чернівецької області протягом 1953-2005 років // Гідрологія, гідрохімія і гідроекологія. - 2007. T.13. - C. 87-94.

14. Дячук В.А. Паводки в Закарпатті та причини їх виникнення / В.А. Дячук, М.М. Сусідко // Укр. географ. журн. - 1999. - №1. - С. 47-50.

15. Условия формирования и прохождения катастрофических паводков на реках Карпат в июне 1969 года (Технический отчет) / Под ред. П.М. Лютика, Б.М. Штейнгольца. - Киев: ГУ ГМС при СМ СССР, 1970. - 54 с.

16. Стихійні метеорологічні явища на території України за останне двадцатиріччя (1986-2005 рр.) / Колектив авторів. За ред. В.М. Ліпінського, В.І. Осадчого, В.М. Бабіченко. - Київ: Ніка-Центр, 2006. - 312 с.

17. Коваленко П.І. Наукові засади комплексного протипаводкового захисту Прикарпатського регіону / П.І. Коваленко, М.І. Ромащенко, Ю.О. Михайлов, Д.П. Савчук // Водне господарство України. - 2008. - №5. - С. 10-23.

18. Директива № 2007/60 / СС Європейського парламенту і Ради ЄС про оцінку і управління ризиками, пов'язаними з повенями (Страсбург, 23 жовтня 2007 року).

19. Руководство по определению расчетных гидрологических характеристик. - Л.: Госметеоиздат, 1984. - $447 \mathrm{c.}$

20. Петроченко В.И. Научно-методическое обоснование систем превентивной противопаводковой защиты территорий в бассейнах рек / В.И. Петроченко, 
А.В. Петроченко // Вестник Брестского государственного технического университета 2018. - №2(110): Водохозяйственное строительство и теплоэнергетика - С. 44-48.

21. Прогнозирование наводнений [Электронный ресурс]: Прогнозирование наводнений / Академия ГПС МЧС России. Официальный сайт - http://www.agppsmipb.ru/index.php/2011-01-08-07-37-51/426-prognosirovanie-navodnenij.html.

22. Басейнове управління водних ресурсів річки Тиса [Електронний ресурс] : Державне агентство водних ресурсів України. Офіційний сайт. Режим доступу: http://www.vodhosp.uzhgorod.ua/aivs_tisa.html.

23. Dellepiane S. Coastline extraction from SAR images and a method for the evaluation of the coastline precision // De Laurentiis R., Giordano F. - Pattern Recognition Letters. - 2004. - № 25. - P. 1461-1470.

24. Скакун С. В. Нейромережевий метод картографування повеней на основі супутникових зображень / С.В. Скакун // Наукові праці ДонНТУ. - 2001. Вип. 10 (153). - С. 52-58. - Серія "Інформатика, кібернетика та обчислювальна техніка".

25. Стефанишин Д.В. Використання методу екстраполяцій при прогнозуванні рівнів води в річці, де відбувається трансформація русла, з врахуванням ризику / Д.В. Стефанишин, Ю.Д. Стефанишина // Гідромеліорація та гідротехнічне будівництво: зб. наук. праць. - Рівне: НУВГП. - 2005.- Вип. 30 - С. 107-116.

26. Методика оцінки збитків від наслідків надзвичайних ситуацій техногенного i природного характеру. Затверджена постановою Кабінету Міністрів України від 15 лютого 2002 р. № 175.

27. Петроченко В.І. Еколого-економічна ефективність протипаводкових заходів / В.І. Петроченко, В.А. Сташук. - К.: ДІУЕВР. - 2009. - 62 с.

Стаття надійшла до редакиії 11.12.2019 і прийнята до друку після рецензування 14.02.2020

\section{REFERENCES}

1. StatInfo.biz - Mezhdunarodnaya ekonomicheskaya statistika. (n.d.). Retrieved from http://statinfo.biz/Data.aspx?act=6467\&lang=1. (in Russian)

2. Petrochenko, A.V. (2018). Problema defitsita vody i pavodkov v Ukraine [The problem of water and flood shortages in Ukraine]. Puti povysheniya effektivnosti oroshayemogo zemledeliya, 3(71), 133-140. (in Russian)

3. Susidko, M.M., \& Lukianets, O.I. (2004). Raionuvannia terytorii Ukrainy za stupenem hidrolohichnoi nebezpeky [Zoning of the territory of Ukraine by the degree of hydrological danger]. Naukovi pratsi UkrNDHMI, 253, 196-202. (in Ukrainian)

4. Alekseyev, N.A. (1988). Stikhiynyye yavleniya v prirode: proyavleniye, effektivnost' zashchity [Natural phenomena in nature: manifestation, protection effectiveness]. Moskva: Mysl'. (in Russian)

5. Nezhikhovskiy, R.A. (1988). Navodneniya na rekakh i ozerakh [Floods on rivers and lakes]. Leningrad: Gidrometeoizdat. (in Russian)

6. Shvets, G.I. (1972). Vydayushchiyesya gidrologicheskiye yavleniya na yugo-zapade SSSR [Outstanding hydrological phenomena in the south-west of the USSR]. Leningrad: Gidrometeoizdat. (in Russian)

7. Koz'menko, S.N. (1997). Ekonomika katastrof (investitsionnyye aspekty) [Disaster Economics (Investment aspects)]. Kyiv: Naukova dumka. (in Russian)

8. Protypavodkovyi zakhyst. Informatsiino-analitychna dovidka shchodo problem kompleksnoho protypavodkovoho zakhystu terytorii rehioniv Ukrainy vid katastrofichnykh pavodkiv ta minimizatsii zbytkiv vid shkidlyvoi dii vod. (n.d.). Derzhavne ahentstvo vodnykh resursiv Ukrainy. Retrieved from http://www.scwm.gov.ua/index.php. (in Ukrainian) 
9. Zamikhovs'kyy, L.M., \& Klapoushchak, O.I. (2011). Analiz metodiv i system kontrolyu ta prohnozuvannya rivnya pavodkovykh vod [Analysis of methods and systems for flood water level control and forecasting]. Naftohazova enerhetyka, 2(15), 99-105. (in Ukrainian) 10. Perekhrest, S.M., Kochubey, S.H., \& Pyechkovs'ka, O.M. (1971). Shkidlyvi stykhiyni yavyshcha $v$ Ukrayins'kykh Karpatakh ta zasoby borot'by z nymy [Natural disasters in the Ukrainian Carpathians and how to combat them]. Kyiv : Naukova dumka. (in Ukrainian) 11. Savchuk, D.P. (2010). Osoblyvosti povenei, pavodkiv ta zakhystu vid nykh u Karpatskomu rehioni [Features of floods, floods and protection against them in the Carpathian region]. Vodne hospodarstvo Ukrainy, 5, 46-49. (in Ukrainian)

12. Karpenko, Yu.O. (1973). Toponimika Bukovyny [Toponymics of Bukovina]. Kyiv: Naukova dumka. (in Ukrainian)

13. Bednarchyk, L.I. (2007). Analiz zmin pavodkovoho rezhymu r. Seret v mezhakh Chernivetskoi oblasti protiahom 1953-2005 rokiv [Analysis of changes in the flood regime of the river Seret in the Chernivtsi region during 1953-2005]. Hidrolohiia, hidrokhimiia $i$ hidroekolohiia, 13, 87-94. (in Ukrainian)

14. Diachuk, V.A., \& Susidko, M.M. (1999). Pavodky v Zakarpatti ta prychyny yikh vynyknennia [Floods in Transcarpathia and their causes]. Ukrainian Geographical Journal, 1, 47-50. (in Ukrainian)

15. Lyutik, P.M., \& Shteyngol'ts, B.M. (Eds.). (1970). Usloviya formirovaniya $i$ prokhozhdeniya katastroficheskikh pavodkov na rekakh Karpat $v$ iyune 1969 goda (Tekhnicheskiy otchet) [Conditions for the formation and passage of catastrophic floods on the Carpathian rivers in June 1969 (Technical Report)]. Kyiv: GU GMS pri SM SSSR. (in Russian)

16. Lipins'kyy, V.M., Osadchyy, V.I., \& Babichenko, V.M. (2006). Stykhiini meteorolohichni yavyshcha na terytorii Ukrainy za ostannie dvadtsatyrichchia (19862005 rr.) [Natural meteorological phenomena in Ukraine over the last twenty years (19862005)]. Kyiv: Nika-Tsentr. (in Ukrainian)

17. Kovalenko, P.I., Romashchenko, M.I., Mykhailov, Yu.O., \& Savchuk, D.P. (2008). Naukovi zasady kompleksnoho protypavodkovoho zakhystu Prykarpatskoho rehionu [Scientific principles of integrated flood protection of the Carpathian region]. Vodne hospodarstvo Ukrainy, 5, 10-23. (in Ukrainian)

18. Directive 2007/60/EC of the European Parliament and of the Council of 23 October 2007 on the assessment and management of flood risks.

19. Rukovodstvo po opredeleniyu raschetnykh gidrologicheskikh kharakteristik [Guidance on the determination of calculated hydrological characteristics] (1984). Leningrad: Gidrometeoizdat. (in Russian)

20. Petrochenko, V.I., \& Petrochenko, A.V. (2018). Nauchno-metodicheskoye obosnovaniye sistem preventivnoy protivopavodkovoy zashchity territoriy $\mathrm{v}$ basseynakh rek [Scientific and methodological substantiation of preventive flood protection systems in river basins]. Brest. Vestnik Brestskogo gosudarstvennogo tekhnicheskogo universiteta: Vodokhozyaystvennoye stroitel'stvo i teploenergetika, 2(110), 44-48. (in Russian)

21. Prognozirovaniye navodneniy. (n.d.). Akademiya GPS MCHS Rossii. Retrieved from http://www.agpps-mipb.ru/index.php/2011-01-08-07-37-51/426-prognosirovanie-

navodnenij.html. (in Russian)

22. Baseinove upravlinnia vodnykh resursiv richky Tysa. (n.d.). Derzhavne ahentstvo vodnykh resursiv Ukrainy. Retrieved from http://www.vodhosp.uzhgorod.ua/aivs_tisa.html. (in Ukrainian)

23. Dellepiane, S., Laurentiis, R., \& Giordano, F. (2004). Coastline extraction from SAR images and a method for the evaluation of the coastline precision. Pattern Recognition Letters, 25, 1461-1470.

24. Skakun, S.V. (2001). Neiromerezhevyi metod kartohrafuvannia povenei na osnovi suputnykovykh zobrazhen [Neural network flood mapping method based on satellite imagery]. Naukovi pratsi Donets'koho NTU. Seriia "Informatyka, kibernetyka ta obchysliuvalna tekhnika", 10(153), 52-58. (in Ukrainian) 
25. Stefanyshyn, D.V., \& Stefanyshyna, Yu.D. (2005). Vykorystannia metodu ekstrapoliatsii pry prohnozuvanni rivniv vody $\mathrm{v}$ richtsi, de vidbuvaietsia transformatsiia rusla, $\mathrm{z}$ vrakhuvanniam ryzyku [Use of extrapolation method for prediction of water levels in river where river bed is transformed, taking into account risk]. Hidromelioratsiia ta hidrotekhnichne budivnytstvo: Zbirnyk naukovykh prats', 30, 107-116. (in Ukrainian)

26. Metodyka otsinky zbytkiv vid naslidkiv nadzvychainykh sytuatsii tekhnohennoho i pryrodnoho kharakteru [Methods of estimation of losses from consequences of emergencies of anthropogenic and natural character]. Zatverdzhena postanovoiu Kabinetu Ministriv Ukrainy vid 15 liutoho 2002 r. № 175. (in Ukrainian)

27. Petrochenko, V.I., \& Stashuk, V.A. (2009). Ekoloho-ekonomichna efektyvnist protypavodkovykh zakhodiv [Ecological and economic efficiency of flood control measures]. Kyiv: DIUEVR. (in Ukrainian)

The article was received 11.12.2019 and was accepted after revision 14.02.2020

\section{Петроченко Олексій Вячеславович}

кандидат технічних наук, помічник ректора Київського національного університету будівництва і архітектури

Адреса робоча: 03037 Україна, м. Київ, проспект Повітрофлотський, 31

e-mail: a_petr89@i.ua

ORCID: ORG/0000-0002-0551-935X 